\title{
Value of Papanicolaou-stained smears in the diagnosis of trichomoniasis, candidiasis, and cervical herpes simplex virus infection in women
}

\author{
R. N. T. THIN, W. ATIA, J. D. J. PARKER, AND C. S. NICOL \\ Special Treatment Centre \\ AND \\ G. CANTI \\ Department of Cytology, St. Bartholomew's Hospital, London, E.C.1
}

Cytologists have recognized Trichomonas vaginalis in stained preparations of cervical and vaginal secretions for some years (Papanicolaou and Traut, 1943). In a small series of women with trichomoniasis, Thin, Melcher, Tapp, Nicol, and Hill (1969) showed that there was no statistical difference between results obtained with cervical smears stained by the Papanicolaou and Pappenheim methods and with fresh wet vaginal preparations; they concluded that an experienced cytologist could make a reliable diagnosis of trichomonal infestation. More recently Wachtel, Wycherley, and Lee (1972) demonstrated that Papanicolaou-stained smears were as reliable as Oxoid Number 2 Trichomonas culture medium in identifying $T$. vaginalis. In the last few years cytologists have recognized the presence of herpes simplex cervicitis by identifying typical large multinucleated 'virocytes' in cervical smears (Nahmias, Naib, Josey, and Clepper, 1967). Beilby, Cameron, Catterall, and Davidson (1968) reported a good correlation between results of herpes virus cultures and cytological changes in a small series of patients. By contrast, in the diagnosis of candidiasis, Cassie and Stevenson (1973) found Sabouraud's medium markedly superior to cervical smears.

We have compared results of Papanicolaou-stained smears with routine smears and cultures in the diagnosis of trichomoniasis, candidiasis, and herpes simplex infection.

\section{Methods}

In all cases a cervical smear was taken with an Ayre spatula, immediately wet-fixed in alcohol-ether, stained by Papanicolaou's method, and examined 'blind' by an experienced cytologist. A wet preparation of vaginal secretion was examined microscopically for $T$. vaginalis. Vaginal secretion was also inoculated into Oxoid No. 2 Trichomonas culture medium. Another smear of vaginal secretion was air-dried, heat-fixed, stained by Gram's method, and examined microsopically for yeast cells and
\end{abstract}

Received for publication July 15, 1974 hyphae; vaginal exudate was also inoculated on to dextrosepeptone agar (Sabouraud's medium) for yeast isolation. Candida species were identified by the cultural and morphological appearances after $48 \mathrm{hrs}$ ' incubation.

In the patients in whom herpes virus studies were carried out, swabs were taken from the cervical os and transported to the laboratory in Hanks's balanced salt solution. There they were inoculated on to human embryonic lung cells. Herpes virus Type 2 was identified by the type of cytopathic effect produced (Parker and Banatvala, 1967).

The patients reported comprise consecutive series in whom the diagnoses were established by one or more of the methods outlined.

\section{Results}

\section{TRICHOMONIASIS}

This was diagnosed by one or more methods in 198 cases. In 119 cases trichomoniasis was associated with another sexually-transmitted disease.

Fresh wet smears gave positive results in 174 (87.8 per cent.) cases, cultures were positive in 156 (78.7 per cent.) cases, and stained smears gave positive results in 169 (85.4 per cent.) cases. There was no significant difference between the proportions positive by stained smear and wet film $(P>0.40)$. The proportion positive by stained smear was marginally greater than the proportion positive by culture $(0.05<\mathbf{P}<0.10)$. The proportion positive by wet film was significantly greater than the proportion positive by culture $(P<0.02)$.

Positive results were obtained by all three methods in 120 cases. Two methods gave positive results in 61 cases. The details are shown in Table I. In seventeen women positive results were obtained by only one method (Table I).

Subsequently the stained smears with results differing from the wet film and/or cultural findings were re-examined. Of the five cases in which the stained smear alone was originally reported as positive, three were confirmed; two were regarded as 
equivocal and on reviewing these two cases it was found that both had several negative wet-film and culture results, so that the original findings can be regarded as false positives. Of the 29 cases in which the stained smear was originally reported as negative, fifteen were confirmed as negative on re-examination, and twelve were found to contain $T$. vaginalis, but in eight the organisms were difficult to identify without prior knowledge. The figures for the cases in which the result was changed are shown in brackets in Table I. During the period under review, 4,000 specimens from the Special Treatment Centre were examined so that the observer error was 0.35 per cent.

TABLE I Comparison of three methods of identifying $\mathrm{T}$. vaginalis

\begin{tabular}{|c|c|c|c|}
\hline No. of cases & Fresh wet smear & Culture & Stained smear \\
\hline $120(+10)$ & + & + & $+(-10)$ \\
\hline 17 & + & + & - \\
\hline $27(+2)$ & + & - & $+(+2)$ \\
\hline 17 & - & + & + \\
\hline 10 & + & - & - \\
\hline 2 & - & + & - \\
\hline $5(-2)$ & - & - & $\rightarrow(-2)$ \\
\hline 198 & 174 & 156 & 169 \\
\hline
\end{tabular}

Figures in brackets show results of reviewing stained smears

In thirteen cases in which the wet film was considered to be negative but another test was positive, a second wet film was examined before treatment, and in eleven cases the second was reported as positive.

\section{CANDIDIASIS}

This was diagnosed by one or more methods in 106 cases. In 47 cases candidiasis was associated with another sexually-transmitted disease.

Gram stain gave positive results in 42 cases (39.7 per cent), Sabouraud cultures were positive in 93 (87.7 per cent.), and Papanicolaou-stained smears were positive in 25 (23.6 per cent.). The proportion positive by Gram stain was significantly greater than the proportion positive by Papanicolaou stain $(P<0.02)$, and the proportion positive by culture was significantly greater than the proportion positive by either of the other two methods $(P<0.001$ in both cases).

Three methods gave positive results in eight patients. Two methods were positive in 38 patients (details are shown in Table II). Gram stain alone gave positive results in nine cases, culture alone was positive in 48 cases and Papanicolaou stain alone was positive in three cases.

\section{CERVICAL HERPES VIRUS INFECTION}

Of a series of 200 consecutive women in whom herpes virus cultures were taken from the cervical os, the virus was isolated from only four, and a fifth patient
TABLE II Comparison of three methods of diagnosing infestation by Candida species

\begin{tabular}{|c|c|c|c|}
\hline No. of cases & $\begin{array}{l}\text { Gram-stained } \\
\text { smear }\end{array}$ & $\begin{array}{l}\text { Sabouraud } \\
\text { culture }\end{array}$ & $\begin{array}{l}\text { Papanicolaou- } \\
\text { stained smear }\end{array}$ \\
\hline 8 & + & + & + \\
\hline 24 & + & + & - \\
\hline 1 & + & - & - \\
\hline 13 & - & + & + \\
\hline 9 & + & - & - \\
\hline 48 & - & $\div$ & - \\
\hline 3 & - & - & + \\
\hline 106 & 42 & 93 & 25 \\
\hline
\end{tabular}

had a positive Papanicolaou-stained smear. Two patients also had other sexually-transmitted diseases.

Culture and stained smear both gave positive results in one patient; three were positive by culture alone and one was positive by smear alone. In four cases the cervix was clinically normal and the fifth had an erosion.

During this investigation cytomegalovirus was isolated from two of the 200 patients.

\section{Discussion}

The findings reported here show that Papanicolaoustained smears are as reliable in the diagnosis of trichomoniasis as either wet films or cultures, but for the highest yield all three methods are indicated. These results are in agreement with the findings reported in other studies (Kean and Day, 1954; Hughes, Gordon and Barr, 1966; Thin and others, 1969; Wachtel and others, 1972). In a small group, Hess (1969) reported a higher proportion of cases giving positive results with the same culture medium, but Cox and Nicol (1973) reported better results with modified Bushby's medium and with FeinbergWhittington medium. The results reported here show that, with experienced observers, the error in identifying $T$. vaginalis in Papanicolaou-stained smears is very low. An advantage of stained smears over the other methods is the permanent specimen available for re-examination.

In contrast, Papanicolaou-stained smears were unsatisfactory in the diagnosis of candidiasis, only 23.6 per cent. being positive by this method. These positive findings are lower than those in similar studies reported by Cassie and Stevenson (1973) and by McLennan, Smith, and McLennan (1972). They support the view of the latter who considered that Papanicolaou-stained smears should not be used routinely for diagnosing candidiasis. Moreover, candidal elements are difficult to identify in Papanicolaou -stained smears; though the number of positive results can be increased by prolonged examination of the smears, the time necessary is not usually available. 
Papanicolaou-stained smears were positive in only two of the five patients with evidence of cervical herpes virus infection; this was suspected clinically in only one of these patients. In another small series, Beilby and others (1968) reported positive smear results in seven of eight cases, and McIndoe and Churchouse (1972) reported positive Papanicolaoustained smears from thirteen of seventeen patients with herpes infection. One explanation of the lowyield from Papanicolaou smears is that cellular changes occur only when there is disease, while cultures may be positive in the presence of inactive virus on the cervix. This inactive virus may be transmitted sexually or during childbirth, and may be related to cervical cancer (Nahmias and Roisman, 1973). While Papanicolaou smears will not detect inactive virus they are of value in picking up unsuspected cases of cervical herpes simplex infection.

\section{Summary}

In the diagnosis of trichomoniasis Papanicolaoustained cervical smears gave marginally better results than cultures of vaginal secretion; stained cervical smears and wet films of vaginal material gave similar results. Culture of vaginal secretion on Sabouraud's medium gave the best results in the diagnosis of candidiasis; Papanicolaou-stained smears gave significantly fewer positive results than either cultures or Gram-stained vaginal smears. Papanicolaoustained smears were reported as positive in only two of five patients with cervical herpes simplex virus infection. It is concluded that Papanicolaou smears are as good as wet films or cultures in the diagnosis of trichomoniasis but cannot be relied on for the diagnosis of candidiasis, or for detecting herpes simplex virus infection.

The authors wish to thank Eileen Barrett, Pamela Donald, Mary St. J. Turner, James Wilson, and Roy Watson for technical help, and Mr. David Smith, Computing Unit for Medical Sciences, for statistical assistance.

\section{References}

Beilby, J. O. W., Cameron, C. H., Catterall, R. D., and Davidson, D. (1968) Lancet, 1, 1065

CAssie, R., and Stevenson, A. (1973) $\mathfrak{f}$. Obstet. Gynaec. Brit. Cwlth, 80, 48
Cox, P. J., and Nicol, C. S. (1973) Brit. F. vener. Dis., 49, 536

Hess, J. (1969) f. clin. Path., 22, 269

Hughes, H. E., Gordon, A. M., and BarR, G. T. D. (1966) f. Obstet. Gynaec. Brit. Cwlth, 73, 821

KeAN, B. H., and DAY, E. (1954) Amer. F. Obstet. Gynec., 68, 1510

McIndoe, W. A., and Churchouse, M. J. (1972) Aust. N.Z.F. Obstet Gynaec., 12, 14

McLennan, M. T., SMith, J. M., and McLennan, C. E. (1972) Obstet. and Gynec., 40, 231

Nahmias, A. J., NaIB, Z. M., Josey, W. E., and Clepper, A. C. (1967) Ibid., 29, 395

- and Rorzman, B. (1973) New Engl. f. Med., 289, 667

Papanicolaou, G. N. and Traut, H. F. (1943) 'Diagnosis of Uterine Cancer by the Vaginal Smear', p. 24. Commonwealth Fund, New York

Parker, J. D. J., and Banatvala, J. E. (1967) Brit. $\mathcal{F}$. vener. Dis., 43, 212

Thin, R. N. T., MELcher, D. H., TAPP, J. W., Nicol, C. S., and HILL, J. (1969) Ibid., 45, 332

WACHTEL, E., WYCHERLEY, J., and LEE, C. N. (1972) Practitioner, 208, 505

Valeur des préparations colorées au Papanicolaou pour le diagnostic de la trichomonase, de la candidose et de l'infection cervicale par le virus de l'herpès simplex chez la femme.

\section{SOMMAIRE}

Pour le diagnostic de la trichomonase, les étalements cervicaux colorés au Papanicolaou fournirent des résultats très peu meilleurs que les cultures de la sécrétion vaginale; les étalements cervicaux colorés et les préparations humides du matériel vaginal donnèrent des résultats similaires. Pour le diagnostic de la candidose, les cultures de la sécrétion vaginale sur milieu de Sabouraud donnèrent les meilleurs résultats; les étalements colorés au Papanicolaou fournirent des résultats significativement moins souvent positifs, soit que les cultures, soit que les étalements vaginaux colorés au Gram. Chez cinq malades atteintes d'une infection cervicale due au virus de l'herpès simplex, on constata que les étalements colorés au Papanicolaou ne furent que deux fois positifs. On en conclut que l'examen des étalements au Papanicolaou valent les préparations humides ou les cultures pour le diagnostic de la trichomonase, mais qu'on ne peut leur faire confiance pour le diagnostic de la candidose ou pour déceler une infection due au virus de l'herpès simplex. 